\title{
Review of Glutamate Intake from Both Food Additive and Non-Additive Sources in the European Union
}

\author{
David R. Tennant \\ Independent Scientific Adviser, Food Chemical Risk Analysis, East Sussex, East Dean, UK
}

\section{Keywords}

Glutamate · Food additive · Estimate · Food ·

European Union

\section{Abstract}

Background: Intakes of glutamate can be derived from its natural occurrence as a constituent of proteins, from the presence of free glutamate in certain fermented foods, and from the addition of glutamic acid and glutamates to foods as flavor-enhancing additives. Summary: Intakes of glutamate following hydrolysis of dietary proteins can be as high as $440 \mathrm{mg} / \mathrm{kg}$ bw/day for toddlers and small children. High-level intakes of glutamate from its natural occurrence in foods or from the use of food additives, given very conservative assumptions about conditions of use, are similar at around $80 \mathrm{mg} / \mathrm{kg}$ bw/day for toddlers and small children. Key Messages: The use of glutamic acid and glutamates as food additives makes a marginal contribution to total intakes of glutamate from all sources.

(c) 2018 The Author(s)

Published by S. Karger AG, Basel

\section{Introduction}

In 2017, the EFSA Panel on Food Additives and Nutrient Sources (ANS) added to Food published a scientific Opinion re-evaluating the safety of glutamic acid-glutamates (E620-E625) when used as food additives [1]. The Opinion concluded that exposure to glutamic acid and glutamates (E620-E625) exceeded not only the proposed accepted daily intake (ADI) $(30 \mathrm{mg} / \mathrm{kg}$ bw/day), but also doses associated with adverse effects in humans for some population groups. However, the panel also considered that uncertainties identified in the exposure assessment would result in an overestimation of the exposure to glutamic acid - glutamates. Although the Opinion did not consider natural sources of exposure to glutamate separately, the use of analytical data on levels of glutamate in many foods meant that contributions to total intakes from natural occurrence could not be excluded.

Glutamate occurs naturally in many common foods so that meat-eaters, fish-eaters, vegetarians, and vegans have similar average background intakes of around $15 \mathrm{~g} /$ day [2]. Much of the glutamate in the normal diet is derived from

\begin{tabular}{|c|c|c|}
\hline KARGER & $\begin{array}{l}\text { () } 2018 \text { The Author(s) } \\
\text { Published by S. Karger AG, Basel }\end{array}$ & $\begin{array}{l}\text { Karger } \\
\text { Open access }\end{array}$ \\
\hline $\begin{array}{l}\text { E-Mail karger@karger.com } \\
\text { www.karger.com/anm }\end{array}$ & $\begin{array}{l}\text { This article is licensed under the Creat } \\
\text { NonCommercial-NoDerivatives } 4.0 \\
\text { BY-NC-ND) (http://www.karger.com/s } \\
\text { se). Usage and distribution for commer } \\
\text { distribution of modified material requi }\end{array}$ & $\begin{array}{l}\text { Commons Attribution- } \\
\text { ernational License (CC } \\
\text { vices/OpenAccessLicen- } \\
\text { al purposes as well as any } \\
\text { written permission. }\end{array}$ \\
\hline
\end{tabular}

David R. Tennant

Food Chemical Risk Analysis

20 Deneside, East Dean

East Sussex BN20 0JG (UK)

E-Mail drt@fcra.co.uk 
the hydrolysis of animal and vegetable proteins. However, certain foodstuffs, particularly those produced by fermentation, can contain significant quantities of natural free glutamate in addition to that found in proteins [3]. The presence of ingredients such as hydrolyzed proteins in food products with no added glutamic acid and glutamates can also result in relatively high glutamate levels [4].

Because of apparent exceedance of the proposed ADI for glutamate from its use as a food additive and uncertainties about the potential contribution of naturally occurring and other sources of dietary glutamate, it is desirable to investigate potential intakes from all sources and to consider the relative contribution from each source separately.

Potential intakes of dietary glutamate have been assessed under the following scenarios:

1. Glutamate intake from naturally occurring free glutamate only.

2. Glutamate intake from dietary protein.

3. Total natural glutamate intake from protein and free glutamate.

4. Free glutamate intake from food additive use.

5. Free glutamate intake from food additive use and naturally occurring free glutamate.

6. Total dietary glutamate intake from all sources combined.

The potential contributions from hydrolyzed vegetable protein (HVP), yeast extracts, and other ingredients have not been considered separately because they are used interchangeably as flavor enhancers with glutamic acid and glutamates (E620-E625). In many cases, the glutamate concentrations associated with HVP or yeast extracts will be lower because of the presence of other flavoring elements. This means that total exposures from these 3 sources can never exceed exposures from glutamic acid and glutamates (E620-E625) assuming that all foods where the additive is permitted actually contain the additive at functional levels. The addition of glutamic acid to foods as a nutrient is intended for foods for specific groups [5] and will not be considered further in this assessment.

\section{Materials and Methods}

\section{Levels of Free Glutamate in Foods}

The Umami Information Centre (UIC) has commissioned the analysis of samples of commonly consumed foods and conducted a literature survey to collate published information about the levels of free glutamate in foods and beverages. Analytical methods, results, and literature sources are available on the UIC web site [6]. The data cover many of the most common categories of food and show that free glutamate is present in almost all foods analyzed and that levels can vary by orders of magnitude between different food types. Foods that are subject to some method of fermentation during production such as cheese and soy sauce frequently have higher free glutamate levels. However, such foods will not necessarily be the main contributors to human exposure, unless consumed in significant amounts. Foods that contain lower amounts of free glutamate but that are eaten more frequently or in larger quantities are likely to have a significant impact on background exposures and so it was important to ensure that these are included in the assessment.

The data included in the UIC database were matched with EFSA FoodEx Level 3 (L3) food descriptions [7] used in the EFSA Comprehensive European Food Consumption Database [8]. Categories for which no free glutamate data were available included pasta, mixed meat/vegetable dishes, ready-to-eat meals, processed fruit products and desserts, including yogurts. Foods where glutamic acid and glutamates are approved as additives or where yeast extracts or HVP could be used as ingredients were excluded. Levels of free glutamate in broader categories at level L2 in the EFSA FoodEx system are summarized in Table 1.

Where a food could be consumed in different forms, the same value was replicated. For example, the value provided for pineapple $(1,136 \mathrm{mg} / \mathrm{kg})$ was also used for pineapple juice and pineapple nectar. The value for "potato" (667 mg/kg) was used for all forms of potato (boiled, fried, etc.) as well as potato-based dishes. Data for a food constituent were also used where that food was a main ingredient of another food such as tomatoes in tomato ketchup.

Data on free glutamate levels in some specific ripened cheese varieties were available and these (averaging several values where necessary) were entered directly. For the broad group "cheese" and for other named cheeses, the average of all cheeses for which data were available was used $(10,221 \mathrm{mg} / \mathrm{kg})$. The natural glutamate occurrence level for bread ( $173 \mathrm{mg} / \mathrm{kg}$ ) was used for all baked goods including breakfast cereals.

After ripened cheeses, soy sauce, sun-dried tomatoes, dried sausages and ham, and tree nuts had the next highest free glutamate levels. Like cheeses, production of soy sauce and dried hams involves fermentation.

\section{Levels of Protein-Bound Glutamate in Foods}

The U.S. Department of Agriculture (USDA), Agricultural Research Service has compiled data on the levels of amino acids in nearly 5,000 common food types [9]. The data are based on highperformance liquid chromatography following acid protein hydrolysis which transforms glutamine to glutamate. To avoid overestimation, all glutamate concentrations have been reduced by a factor of 0.4 as recommended by Beyreuther et al. [10] so that they represent glutamate derived from protein-bound glutamate only. The analysis will also detect free glutamates, and to reduce this factor, foods such as fermented products (including cheese) which are known to contain raised levels of free glutamate, have been excluded. Levels of bound glutamate in broader categories at level L2 in the EFSA FoodEx system are summarized in Table 1.

Average levels of glutamate in animal and vegetable products were extracted from the USDA system and paired with 570 EFSA FoodEx Level 3 (L3) food codes from the EFSA Comprehensive European Food Consumption Database (Table 1). Where more than one USDA food category matched an EFSA FoodEx category, the average value was used. The highest levels of glutamate occurred in eggs and egg products (around 14,400 mg/kg overall), meat and meat products, and fish and seafood (around 12,000 mg/kg overall). 
Table 1. Levels of free and bound glutamate in broad food categories

\begin{tabular}{|c|c|c|}
\hline FoodEx category (L2) & $\begin{array}{l}\text { Average free } \\
\text { glutamate }\end{array}$ & $\begin{array}{l}\text { Average bound } \\
\text { glutamate* }\end{array}$ \\
\hline Alcoholic beverages & 10 & 240 \\
\hline Animal and vegetable fats and oils & 18 & \\
\hline Composite food (including frozen products) & 98 & 9,353 \\
\hline \multicolumn{3}{|l|}{ Drinking water } \\
\hline Eggs and egg products & 48 & 14,360 \\
\hline Fish and other seafood & 489 & 12,055 \\
\hline Food for infants and small children & n.d. & 3,542 \\
\hline Fruit and fruit products & 84 & 440 \\
\hline Fruit and vegetable juices & 218 & \\
\hline Grains and grain-based products & 98 & 9,063 \\
\hline Herbs, spices, and condiments & 253 & \\
\hline Legumes, nuts, and oilseeds & 1,250 & 11,162 \\
\hline Meat and meat products (including edible offal) & 776 & 12,065 \\
\hline Milk and dairy products & 6,857 & 2,830 \\
\hline Non-alcoholic beverages (excepting milk-based) & 32 & 1,653 \\
\hline Other foods & 55 & \\
\hline Products for special nutritional use & n.d. & \\
\hline Snacks, desserts, and other foods & 35 & 4,440 \\
\hline \multicolumn{3}{|l|}{ Sugar and confectionary } \\
\hline Vegetables and vegetable products (including fungi) & 515 & 2,164 \\
\hline
\end{tabular}

* Adjusted by $40 \%$ to allow for the presence of glutamate from glutamine in analyzed samples. n.d., no data.

Levels of Glutamate from Food Additive Use

Data on levels of glutamic acid and glutamates (E620-E625) were taken from Appendix E (concentration levels of glutamic acid-glutamates (E620-E625) used in the exposure scenarios) of the EFSA ANS Opinion [1] re-evaluating the safety of glutamic acidglutamates. The data-set included all food categories where glutamic acid-glutamates (E620-E625) are authorized and where data were available. In addition to data on actual use levels provided by the food industry, analytical data provided by Member States were included irrespective of whether the glutamate was derived from food additives or natural sources. Levels used in the refined exposure assessment from Appendix E of the ANS Opinion were matched with EFSA FoodEx Level 3 (L3) food descriptions used in the EFSA Comprehensive European Food Consumption Database.

The highest use levels were for category "12.2.2 Seasonings and condiments" $(208,700 \mathrm{mg} / \mathrm{kg})$ followed by "07.2 Fine bakery wares" and "15.1 Potato-, cereal-, flour- or starch-based snacks" (both at $10,000 \mathrm{mg} / \mathrm{kg}$ ).

\section{Food Consumption Data and Exposure Model}

Food consumption data expressed in grams per kilogram bodyweight per day ( $\mathrm{g} / \mathrm{kg}$ bw/day) were drawn from the published version of the EFSA Comprehensive European Food Consumption Database at level L3 and incorporated into a deterministic exposure model [11]. For each food category and for each country/age group combination, the exposure model adds the 95th percentile "consumers only" intake to the average population intake from all other foods, to estimate high-level total intake associated with that food category. The highest high-level total intake associated with any food category is taken to be the high-level intake for that country/age group combination. This value is broadly equivalent to the 95th percentile in other exposure models. Results are expressed as the range of average and high-level intakes across all countries in each age range.

\section{Results}

\section{Glutamate Intake from Naturally Occurring Free Glutamate Only}

Average population intakes of free glutamate ranged from $5.5 \mathrm{mg} / \mathrm{kg}$ bw/day (elderly Austrians) to $37 \mathrm{mg} / \mathrm{kg}$ bw/day (toddlers in Belgium; Table 2). Ripened cheese (either unspecified or relating to specific cheese types) contributes most to average intakes followed by preserved meats but also in some cases, milk, potatoes, and tomatoes can be significant.

High-level intakes range up to $82 \mathrm{mg} / \mathrm{kg}$ bw/day for other children in Belgium, $77 \mathrm{mg} / \mathrm{kg}$ bw/day for Danish infants, and $56 \mathrm{mg} / \mathrm{kg}$ bw/day for other children in Bulgaria. High-level intake in Danish infants relates to the consumption of infant formula based on protein hydrolysates, and so might be regarded as an exception. High-level intakes relate to high consumption of cheese of various types. 
Table 2. Intakes of free glutamates from natural occurrence in food and drinks

\begin{tabular}{|c|c|c|c|c|c|c|}
\hline \multicolumn{7}{|c|}{ Natural free glutamate } \\
\hline Mean & $10-22$ & $15-37$ & $12-31$ & $8-17$ & $7-15$ & $5-17$ \\
\hline High level & $21-77$ & $20-54$ & $18-82$ & $12-28$ & $11-36$ & $11-27$ \\
\hline
\end{tabular}

Table 3. Intakes of glutamate from dietary protein

\begin{tabular}{|c|c|c|c|c|c|c|}
\hline & $\begin{array}{l}\text { Infants } \\
\text { (12 weeks-11 months) }\end{array}$ & $\begin{array}{l}\text { Toddlers } \\
\text { (12-35 months) }\end{array}$ & $\begin{array}{l}\text { Children } \\
\text { (3-9 years) }\end{array}$ & $\begin{array}{l}\text { Adolescents } \\
\text { (10-17 years) }\end{array}$ & $\begin{array}{l}\text { Adults } \\
\text { (18-64 years) }\end{array}$ & $\begin{array}{l}\text { Elderly } \\
\text { ( } \geq 65 \text { years) }\end{array}$ \\
\hline \multicolumn{7}{|c|}{ Natural protein-bound } \\
\hline High level & $121-361$ & $286-444$ & $173-326$ & $104-192$ & $95-145$ & $71-138$ \\
\hline
\end{tabular}

Table 4. Intakes of glutamate from natural free glutamate and dietary protein

\begin{tabular}{|c|c|c|c|c|c|c|}
\hline & $\begin{array}{l}\text { Infants } \\
\text { (12 weeks-11 months) }\end{array}$ & $\begin{array}{l}\text { Toddlers } \\
\text { (12-35 months) }\end{array}$ & $\begin{array}{l}\text { Children } \\
\text { (3-9 years) }\end{array}$ & $\begin{array}{l}\text { Adolescents } \\
\text { (10-17 years) }\end{array}$ & $\begin{array}{l}\text { Adults } \\
\text { (18-64 years) }\end{array}$ & $\begin{array}{l}\text { Elderly } \\
\text { ( } \geq 65 \text { years) }\end{array}$ \\
\hline \multicolumn{7}{|c|}{ Natural total glutamate } \\
\hline High level & $132-381$ & $310-468$ & $193-358$ & $113-206$ & $106-155$ & $76-126$ \\
\hline
\end{tabular}

Data are expressed as mg glutamic acid/kg bw/day.

\section{Glutamate Intake from Dietary Protein}

Average population intakes of glutamate from dietary protein ranged from $68 \mathrm{mg} / \mathrm{kg}$ bw/day (UK elderly) to $307 \mathrm{mg} / \mathrm{kg}$ bw/day (toddlers in Spain; Table 3). Toddlers have the highest average intakes, probably related to their higher energy demands overall. High-level intakes ranged to $444 \mathrm{mg} / \mathrm{kg}$ bw/day for toddlers in Finland. The main sources of high-level intakes were cows' milk for children and meat and some cereal products for adults.

\section{Total Natural Glutamate Intake from Protein and}

\section{Free Glutamate}

When levels of free glutamate and that derived from protein were added and entered into the exposure model, intake estimates were very similar to those from protein alone. Average population intakes ranged from $76 \mathrm{mg} / \mathrm{kg}$ bw/day (UK elderly) to $331 \mathrm{mg} / \mathrm{kg}$ bw/day (toddlers in
Spain; Table 4) and high-level intakes ranged to $468 \mathrm{mg} /$ $\mathrm{kg}$ bw/day for toddlers in Finland. This result is to be expected because protein-derived glutamate concentrations are generally orders of magnitude higher than free glutamate levels. The main sources of high-level intakes were again cows' milk for children and meat and some cereal products for adults.

\section{Free Glutamate from Addition of E620-E625}

When data on use levels from Appendix E of the ANS Opinion on glutamates [1] were entered into the model average population intakes ranged from $2 \mathrm{mg} / \mathrm{kg}$ bw/day (elderly adults in Denmark) to $37 \mathrm{mg} / \mathrm{kg}$ bw/day (toddlers in Belgium; Table 5) and high-level intakes ranged up to $82 \mathrm{mg} / \mathrm{kg}$ bw/day for toddlers in the UK. Because they are based on the same use levels, the results are very similar to those provided in the ANS Opinion for the 
Table 5. Intakes of free glutamates from use of E620-E625 in food and drinks

\begin{tabular}{|c|c|c|c|c|c|c|}
\hline & $\begin{array}{l}\text { Infants } \\
\text { (12 weeks-11 months) }\end{array}$ & $\begin{array}{l}\text { Toddlers } \\
\text { (12-35 months) }\end{array}$ & $\begin{array}{l}\text { Children } \\
\text { (3-9 years) }\end{array}$ & $\begin{array}{l}\text { Adolescents } \\
(10-17 \text { years })\end{array}$ & $\begin{array}{l}\text { Adults } \\
\text { (18-64 years) }\end{array}$ & $\begin{array}{l}\text { Elderly } \\
\text { ( } \geq 65 \text { years) }\end{array}$ \\
\hline \multicolumn{7}{|l|}{ E620-E625 } \\
\hline Mean & $6-12$ & $6-37$ & $7-31$ & $4-10$ & $2-13$ & $2-15$ \\
\hline High level* & $18-59$ & $20-82$ & $17-76$ & $11-45$ & $7-35$ & $4-34$ \\
\hline
\end{tabular}

* Non-brand-loyal scenario. Data are expressed as mg glutamic acid/kg bw/day.

Table 6. Intakes of free glutamates from the use of E620-E625 in food and drinks reported in EFSA opinion (EFSA 2017a)

\begin{tabular}{llllll}
\hline & $\begin{array}{l}\text { Infants } \\
(12 \text { weeks-11 months })\end{array}$ & $\begin{array}{l}\text { Toddlers } \\
(12-35 \text { months })\end{array}$ & $\begin{array}{l}\text { Children } \\
(3-9 \text { years })\end{array}$ & $\begin{array}{l}\text { Adolescents } \\
(10-17 \text { years })\end{array}$ & $\begin{array}{l}\text { Adults } \\
(18-64 \text { years })\end{array}$ \\
\hline $\begin{array}{l}\text { E620-E625 } \\
\text { Mean }\end{array}$ & $5-19$ & $19-51$ & $9-47$ & $3-27$ & $5-19$ \\
95th percentile* & $20-65$ & $35-88$ & $17-93$ & $7-59$ & $9-42$ \\
\hline
\end{tabular}

* Non-brand-loyal scenario. Data are expressed as mg glutamic acid/kg bw/day.

Table 7. Intakes of free glutamates from the use of E620-E625 and natural occurrence of free glutamate

\begin{tabular}{|c|c|c|c|c|c|c|}
\hline & $\begin{array}{l}\text { Infants } \\
\text { (12 weeks-11 months) }\end{array}$ & $\begin{array}{l}\text { Toddlers } \\
\text { (12-35 months) }\end{array}$ & $\begin{array}{l}\text { Children } \\
\text { (3-9 years) }\end{array}$ & $\begin{array}{l}\text { Adolescents } \\
(10-17 \text { years })\end{array}$ & $\begin{array}{l}\text { Adults } \\
\text { (18-64 years) }\end{array}$ & $\begin{array}{l}\text { Elderly } \\
\text { ( } \geq 65 \text { years) }\end{array}$ \\
\hline \multicolumn{7}{|c|}{ Total free glutamate } \\
\hline Mean & $16-29$ & $26-74$ & $28-60$ & $18-30$ & $13-23$ & $11-25$ \\
\hline High level & $30-85$ & $50-111$ & $39-112$ & $26-57$ & $18-46$ & $16-43$ \\
\hline
\end{tabular}

Data are expressed as mg glutamic acid/kg bw/day.

non-brand-loyal scenario (Table 6), although different exposure methodologies were applied.

The main sources of high-level intakes for all age groups were pastries and cakes and soups.

\section{Total Free Glutamate from E620-E625 and Natural \\ Free Glutamate}

Total free glutamate intake estimates were based on E620-E625 use levels from Appendix E of the ANS Opinion [1] and natural free glutamate levels combined. Average population intakes ranged from $11 \mathrm{mg} / \mathrm{kg}$ bw/ day (Danish elderly) to $74 \mathrm{mg} / \mathrm{kg}$ bw/day (toddlers in Belgium; Table 7) and high-level intakes ranged to over $110 \mathrm{mg} / \mathrm{kg}$ bw/day for toddlers in Bulgaria and other children in Belgium. The main sources of high-level intakes for all age groups were pastries and cakes and ripened cheeses of all types.

Dietary Glutamate Intake Estimate

\section{Total Glutamate}

Total glutamate intakes were estimated by combining data on natural fee glutamate, glutamate derived from protein, and glutamate from additive E620-E625. Average population intakes ranged from $88 \mathrm{mg} / \mathrm{kg}$ bw/day (UK elderly) to $346 \mathrm{mg} / \mathrm{kg}$ bw/day (toddlers in Spain; Table 8) and high-level intakes ranged to $474 \mathrm{mg} / \mathrm{kg}$ bw/day for toddlers in Finland. The main sources of high-level intakes were again cows' milk for children and meat and some cereal products for adults.

\section{Uncertainty Analysis}

Sources of uncertainty identified in the 2017 EFSA ANS Opinion on glutamic acid-glutamates (E620-E625) as food additives [1] will cause similar uncertainties in the present assessment. In particular, the distinction between glutamate naturally present in food, added as a food ad- 
Table 8. Intakes of glutamate from all sources

\begin{tabular}{lllllr}
\hline & $\begin{array}{l}\text { Infants } \\
(12 \text { weeks-11 months })\end{array}$ & $\begin{array}{l}\text { Toddlers } \\
(12-35 \text { months })\end{array}$ & $\begin{array}{l}\text { Children } \\
(3-9 \text { years })\end{array}$ & $\begin{array}{l}\text { Adolescents } \\
(10-17 \text { years })\end{array}$ & $\begin{array}{l}\text { Adults } \\
(18-64 \text { years })\end{array}$ \\
\hline $\begin{array}{l}\text { Total glutamate } \\
\text { Mean }\end{array}$ & $98-211$ & & & & \multicolumn{1}{c}{$\begin{array}{l}\text { Elderly } \\
(\geq 65 \text { years })\end{array}$} \\
$\quad$ High level & $137-388$ & $244-346$ & $167-319$ & $92-170$ & $88-126$ \\
\hline
\end{tabular}

Data are expressed as mg glutamic acid/kg bw/day.

ditive or present as a nutrient cannot be made using analytical data alone. However, in many cases information about the nature of food and the patterns of use of additives and nutrients can help to identify foods where additives could be present or not. For example, the use of analytical data for foods such as breakfast cereals, cakes, and cookies is unrealistic because the additive is used to enhance the "umami" flavor in savory foods. This will probably cause significant overestimation of intakes from E620-E625 for high consumers of such foods.

The E620-E625 intake estimate also assumed that $100 \%$ of every approved category contained the additive although the Mintel Global New Products Database database (Appendix D of the ANS Opinion) [1] showed that in the majority of cases less than $2 \%$ of foods in a given category contained the additive. In particular, only $0.4 \%$ of "Fine bakery wares," which was the category identified by the ANS Panel as the main contributor to intake, contained E620-E625. This would probably relate only to savory crackers, which could be regarded as an exception under "fine bakery wares." The use of HVP and yeast extracts as flavor enhancers are unlikely to increase the total glutamate intakes because they are used in place of E620E625 in some foods.

Data on the levels of free glutamate in foods are incomplete and have largely focused on foods where higher levels are expected. This has meant that it is difficult to estimate background intakes contributing to total intakes from the entire diet. In this study this problem has been addressed by extrapolating data from key foods, such as potatoes to cover all variants of that food. However, large data gaps remain and values were available for only about one half of all food categories at level L3 in the EFSA Foo$\mathrm{dEx}$ coding system. Provided that these data gaps relate to foods with relatively low glutamate content the effect should be minimal.

Uncertainties also relate to the values used for foods where higher levels of glutamate are reported. This is because the free glutamate concentration is likely to be highly variable, particularly where it is a product of fermentation. Since glutamate levels increase during aging, it is difficult to determine a representative value since local tastes and culture will lead to products at different levels of maturity being consumed. High glutamate levels have been traditionally associated with certain matured cheeses such as Parmigiano reggiano. However, this study has seen relatively high concentrations in soft cheeses such as brie $(18,560 \mathrm{mg} / \mathrm{kg})$, possibly if allowed to fully ripen.

Glutamine and glutamate are present in dietary proteins in approximately equal amounts [12]. Analytical acid pre-hydrolysis will cause glutamine in proteins to be determined as glutamate. Applying a correction factor of $40 \%$ will lead to some uncertainty if the ratio of glutamine to glutamate varies between proteins.

Since foods such as fermented products (including cheese), which are known to contain raised levels of free glutamate, were excluded from the assessment, and glutamate levels in other foods are orders of magnitude lower than glutamate from protein, free glutamate will have contributed only marginally to estimates of glutamate from protein.

Overall, uncertainties would result in an overestimation of the exposure to glutamic acid-glutamates (E620E625) as food additives, overestimation of exposure to glutamate from derived protein in the diet and possible underestimation of intakes of free glutamate from natural sources. However, estimates are close to previous estimates in the ANS Opinion [1] and published literature [4, 13 ] and hence provide a reasonable basis for comparison.

\section{Discussion}

Methodological issues affect the reliability of analyses for glutamate in food because it is not possible to discriminate between free natural glutamate, glutamate derived from glutamine or glutamate in proteins, 
Fig. 1. Maximum national high-level intakes of glutamate from all sources.

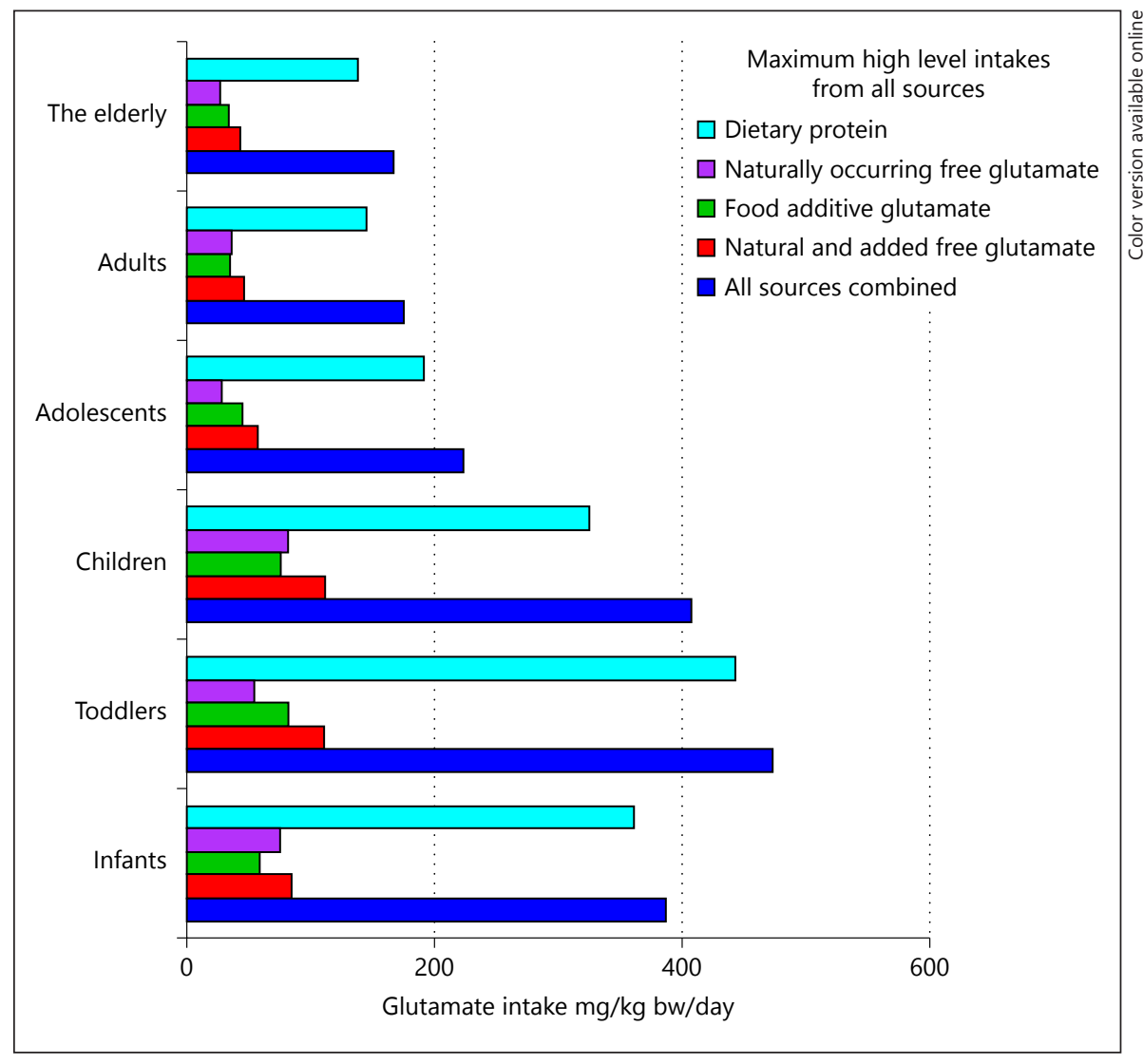

or glutamate added as a food additive or nutrient. Nevertheless, careful selection of samples with known origin and composition can help reduce uncertainties by grouping foods known to have high free glutamate levels, foods with high protein levels and foods where glutamate addition for flavor enhancement or nutrition may be appropriate.

Glutamate from protein is the greatest source of exposure, contributing over $400 \mathrm{mg} / \mathrm{kg}$ bw/day in some cases. The principal origin of such glutamate is usually cows' milk although meat (including chicken and fish) and certain cereal-based products can be important for some individuals.

Potential intakes from food additive uses of glutamate and from natural free glutamate are at least an order of magnitude lower than intakes from protein-bound glutamate and are very similar to each other (Fig. 1). Whilst estimates of intake from food additive uses are likely to be very conservative because of the assumption of $100 \%$ usage across broad categories such as "fine bakery wares," estimates of natural free glutamate are likely to be more reliable or may underestimate real exposures slightly. When added together, total hypothetical intakes are dou-

Dietary Glutamate Intake Estimate bled for average consumers and increased by about one third for high-level consumers.

Adding intakes of glutamate from food additive use to total exposure from natural sources results in an increase in total intake of about $8 \%$ for average consumers and about 19\% for the highest high-level consumers.

\section{Conclusion}

Glutamic acid and glutamates are ubiquitous in foods high in protein. Digestion of glutamic acid in proteins can result in intake of free glutamate, and glutamine in proteins may also make a contribution. Levels of glutamate after acid hydrolysis can be as high as $50,000 \mathrm{mg} / \mathrm{kg}$ in certain oilseeds. Levels of glutamate from protein in animal products are generally around $25,000 \mathrm{mg} / \mathrm{kg}$.

Free glutamates can occur in relatively high concentrations in certain fermented foods such as cheese, preserved meats, and soy sauce. Free glutamate levels appear to be highly variable, probably related to the degree of aging and maturation, and can rise to over $18,000 \mathrm{mg} / \mathrm{kg}$. 
Additive use levels for glutamic acid and glutamate (E620-E625) are limited to $10,000 \mathrm{mg} / \mathrm{kg}$ in 65 broad categories of foods (except for seasonings) by the provisions of European Food Additive Regulations [14, 15]. However, glutamic acid and glutamates would only be used in savory foods where there is a need to enhance the "umami" taste of the food and so would be used in only a small proportion of the foods for which it is authorized.

Conservative assessments of potential high-level intakes of glutamates and glutamic acid from the use of E620-E625 range up to around $80 \mathrm{mg} / \mathrm{kg}$ bw/day for toddlers and other children. Estimated high-level intakes of free glutamate from natural sources give a very similar result. Intakes of glutamate from amino acids in proteins can range to over $400 \mathrm{mg} / \mathrm{kg}$ bw/day for the same age groups.

The use of glutamic acid and glutamates as food additives, therefore, results in free glutamate intakes very similar to those from natural sources and makes a marginal contribution to total intakes of glutamate from all sources.

\section{Acknowledgement}

Analytical data and data from scientific literature on occurrence of free glutamate in foods were supplied by the UIC. http:// www.umamiinfo.com/umamidb/.

\section{Ethics Statement}

The author has no ethical conflicts to disclose.

\section{Disclosure Statement}

The author has no conflicts of interest to declare.

\section{Funding Sources}

Research was funded by Ajinomoto Co., Inc. (Tokyo, Japan). The Workshop preparation, setting, and attendance were supported by the International Glutamate Technical Committee (IGTC), Brussels. The views of the author are his own, and do not necessarily reflect those of the IGTC.

\section{References}

1 EFSA Panel on Food Additives and Nutrient Sources added to Food (ANS), Mortensen A, Aguilar F, Crebelli R, Di Domenico A, Dusemund B, Frutos MJ, et al: Re-evaluation of glutamic acid (E 620), sodium glutamate (E 621), potassium glutamate (E 622), calcium glutamate (E 623), ammonium glutamate (E 624) and magnesium glutamate (E 625) as food additives. EFSA J 2017;15:4910.

2 Schmidt JA, Rinaldi S, Scalbert A, Ferrari P, Achaintre D, Gunter MJ, Appleby PN, Key TJ, Travis RC: Plasma concentrations and intakes of amino acids in male meat-eaters, fish-eaters, vegetarians and vegans: a cross-sectional analysis in the EPIC-Oxford cohort. Eur J Clin Nutr 2016;70:306-312.

3 Ninomiya K: Natural occurrence. Food Rev Int 1998;14:177-211.

4 Populin T, Moret S, Truant S, Conte LS: A survey on the presence of free glutamic acid in foodstuffs, with and without added monosodium glutamate. Food Chemistry 2007;104: 1712-1717.

5 Regulation (EC) No 609/2013 of the European Parliament and of the Council of 12 June 2013 on Food Intended for Infants and Young Children, Food for Special Medical Purposes, and Total Diet Replacement for Weight Control and Repealing Council Di- rective 92/52/EEC, Commission Directives 96/8/EC, 1999/21/EC, 2006/125/EC and 2006/141/EC, Directive 2009/39/EC of the European Parliament and of the Council and Commission Regulation (EC) No 41/2009 and (EC) No 953/2009. OJL 181, 29.6.2013, pp 35-56.

6 International Umami Council. http://www. umamiinfo.com/umamidb/.

7 FoodEx2 (version 2 of the EFSA Food Classification and Description System for Exposure Assessment). https://www.efsa.europa. eu/en/data/data-standardisation.

8 The EFSA Comprehensive European Food Consumption Database. https://www.efsa. europa.eu/en/food-consumption/comprehensive-database.

9 US Department of Agriculture, Agricultural Research Service (2014). National Nutrient Database for Standard Reference, Release 26, 2013 (updated July 2, 2014; cited 2014, 10 April to 6 May). http://www.ars.usda.gov/ba/ bhnrc/ndl.

10 Beyreuther K, Biesalski HK, rnstrom JD, Grimm P, Hammes WP, Heinemann U, Kempski O, Stehle P, Steinhart H, Walker R: Consensus meeting: monosodium glutamate - an update. Eur J Clin Nutr 2007;61: 304-313.
11 Tennant DR: Comprehensive European dietary exposure model (CEDEM) for food additives. Food Addit Contam Part A Chem Anal Control Expo Risk Assess 2016;33:772781

12 Ma W, Heianza Y, Huang T, Wang T, Sun D, Zheng Y, Hu FB, Rexrode KM, Manson JE, Qi $\mathrm{L}$ : Dietary glutamine, glutamate and mortality: two large prospective studies in US men and women. Int J Epidemiol 2018;47:311320.

13 Iwasaki M, Ishihara J, Takachi R, Todoriki H, Yamamoto H, Miyano H, Yamaji T, Tsugane S: Validity of a self-administered foodfrequency questionnaire for assessing amino acid intake in Japan: comparison with intake from 4-day weighed dietary records and plasma levels. J Epidemiol 2016;26:3644.

14 EC (2008). Regulation (EC) No $1333 / 2008$ of the European Parliament and of the Council of 16 December 2008 on Food Additives. OJL $354 / 16,31.12 .2008$

15 EC (2011). Commission Regulation (EU) No 1129/2011 of 11 November 2011 Amending Annex II to Regulation (EC) No 1333/2008 of the European Parliament and of the Council by Establishing a Union List of Food Additives. OJL 295/1, 12.11.2011. 